\title{
A new screening model for leachate production assessment at landfill sites
}

\author{
S. Pantini $\cdot$ I. Verginelli $\cdot$ F. Lombardi
}

Received: 21 January 2013/Revised: 3 May 2013/Accepted: 26 May 2013/Published online: 10 July 2013

(C) Islamic Azad University (IAU) 2013

\begin{abstract}
This paper presents an alternative water balance model for predicting leachate production in landfills, from the operative to the post-closure management. The developed model, based on analytical and empirical equations, provides a quantitative estimation of leachate volumes, using a water balance approach which accounts for the different rates of the incoming water, water losses and water consumption. Aging and compression are also included, allowing to assess the progressive variation of hydraulic and physical properties of deposited wastes. In this work, after a brief description of the model architecture, different applications to hypothetical scenarios and to a real landfill are presented. Namely, in order to highlight how aging and biodegradation can influence the expected leachate production, the results of the developed model are also compared with those provided by the Hydrologic Evaluation of Landfill Performance model which neglects both these processes. The obtained results showed that wastes compression may affect leachate prediction in a large extent during operative stage of a landfill, and neglecting these processes could lead to underestimation up to one order of magnitude. Also biodegradation of waste organic matter may result relevant for leachate volumes assessment, influencing water storage capacity of wastes and leading to a leachate production 2-3 times greater than those obtained neglecting these phenomena. Finally, the application of the developed model to the real landfill shows a quite good agreement with the field data, whereas the Hydrologic Evaluation of Landfill Performance model
\end{abstract}

S. Pantini $(\square) \cdot$ I. Verginelli $\cdot$ F. Lombardi Department of Civil Engineering and Computer Science Engineering, University of Rome "Tor Vergata", Via del Politecnico, 1, 00133 Rome, Italy e-mail: pantini@ing.uniroma2.it tends to underestimate the leachate volumes with errors up to $80 \%$.

Keywords Biological-hydrological processes .

Compression · Percolate - Water balance model - Wastes

\section{Introduction}

Municipal solid waste landfill can represent a source of main environmental impacts closely linked to the potential emission of leachate and landfill gas, which may cause groundwater pollution, soil contamination and global warming effects (Aronica et al. 2009; Sivakumar 2012; Thomsen et al. 2012; Zaman 2010). In order to manage and control landfills in an efficient way, so that environmental loadings are minimized for short and long time periods, understanding landfill behavior is crucial (Fellner and Brunner 2010). In particular, the pollutant load to the environment is dependent on the quantity and the quality of the water that percolates through the landfill (Kale et al. 2010, Papadopoulou et al. 2007, Renou et al. 2008). Thus, estimate leachate generation and transport during the life of a landfill is a key issue in order to reduce its potential risk (Sivakumar 2013). To this end, an useful tool is represented by simulation models based on the water balance method. However, the development of a model which is suitable to different specific landfills contexts is complex (Lobo and Tejero 2007, Han et al. 2011) because of the influence on the water balance of local factors, such as meteorological condition, composition and hydro-physical properties of wastes, filling methods, as well as the influence of physical, biological and chemical processes, e.g., generation and migration of gas and fluid, biological and chemical degradation of waste and materials aging (Oni 
and Okunade 2009; São Mateus et al. 2012). All these phenomena and factors are mutually dependent and usually vary in space and time (Oni and Okunade 2009; Sirini et al. 2010). For instance, waste field capacity, porosity and hydraulic conductivity of the refuse decrease over time due to the applied overpressure (which increases with the progressive landfilling) and the degradation of waste organic matter (Di Bella et al. 2012; Machado et al. 2010; Powrie et al. 2000; Reddy et al. 2011; Staub et al. 2009; Stoltz et al. 2010; Wu et al. 2012).

In the last decades, several mathematical models have been developed to simulate the generation and transport of leachate in landfills. The most widely used package is the Hydrologic Evaluation of Landfill Performance, HELP (Schroeder et al. 1994), even though in the last years its use is questioned as a number of limitations have been detected (Berger 2000; Lobo et al. 2003; Murthy et al. 2009; Oni 2010; São Mateus et al. 2012; Shariatmadari et al. 2010). The HELP model has been designed to conduct water balance analyses of open, partially closed and fully closed landfills (Schroeder et al. 1994), but actually it does not allow to reproduce the progressive development of a landfill, the aging of materials and other important processes that affect leachate generation (e.g., biodegradation reaction, waste compression and consolidation and change in waste physico-mechanical properties). Indeed, the HELP model assumes constant parameters and simulates the leachate transport and generation after all solid wastes are placed and stability conditions of refuse are reached. In order to overcome these limitations, several integrated models have been developed (e.g., De Velásquez et al. 2003a; Kindlein et al. 2003; White et al. 2004; Zacharof and Butler 2004; Lobo and Tejero 2007; São Mateus et al. 2012) that consider both leachate and gas generation due to biological transformation of organic matter, simulating jointly hydrological and degradation phenomena. These models differ by the underlying assumptions and the conditions at which they can be applied. In this paper, an alternative model Landfill Water Balance model (LWB), accounting for all the key processes leading to leachate production while keeping an analytical simple approach, is presented. The model, based on analytical and empirical equations, allows to predict leachate volume during the entire life of a landfill, from the operative stage to the aftercare period taking into account all the principal factors and processes that affect the water balance. The main features of the model are reported in Table 1. In this paper, after a brief description of the model architecture, different applications to some hypothetical scenarios and to a real landfill are presented. Namely, the first simulations are aimed to highlight for which site and waste conditions, compression and biodegradation of refuse are expected to influence the leachate production. To this end, the results obtained by applying the developed model for different municipal solid waste (MSW) properties are compared with HELP which neglects both these processes. Next, an application of the developed model to a real landfill is presented. The considered landfill is located in the center of Italy and is currently in operative management stage. The simulations were carried out over a period of almost 4 years (from January 2009 till October 2012) and the predicted values, obtained with both the LWB and the HELP model, were compared with the landfill measurements of the leachate flow in the final collection pipes.

\section{Materials and methods}

The developed model accounts for the progressive variation of landfill geometry, during the operative stage, as well as temporal changes of waste hydraulic and physico-mechanical properties since their disposal. These features may lead to a more realistic estimation of the leachate production over time. The code reproduces wastes disposal and management methods as the overall landfill system is discretized in different elements: the cells. For each cell, the number of layers $Z_{j}$, the surface area, the thickness, the progressive time of layers disposal, the hydrological properties, and the type of the wastes (e.g., municipal solid wastes, bio-stabilized organic fraction, mechanical-biological treatment scraps, etc.) can be defined. For the post-closure management, further information related to the capping system (i.e., vegetation and soil cover, lateral drain layers, low permeability barrier soils and geomembrane liners) can be introduced.

\section{Water balance}

The developed model provides a quantitative estimation of leachate volumes by applying the water balance to each layer $Z_{j}$ composing the single cell. At each time $t_{i}$, the model calculates all the water inputs and outputs, as follows (Eq. 1):

$$
\begin{aligned}
L\left(Z_{j}, t_{i}\right)= & W_{\text {in }}\left(Z_{j}, t_{i}\right)+W_{\text {rel }}\left(Z_{j}, t_{i}\right)-W_{\text {ret }}\left(Z_{j}, t_{i}\right) \\
& -W_{\text {bio }}\left(Z_{j}, t_{i}\right)-W_{\text {vap }}\left(Z_{j}, t_{i}\right)-\Delta Q_{\text {lat }}\left(Z_{j}, t_{i}\right)
\end{aligned}
$$

where $L$ is the leachate produced by the $j t h$ layer, $\mathrm{W}_{\text {in }}$ is the incoming water in wastes, $W_{\text {rel }}$ and $W_{\text {ret }}$ represent the released and retained water by waste, respectively, $W_{\text {bio }}$ is the biotic water consumption, $W_{\text {vap }}$ the loss of water as vapor in biogas and $\Delta Q_{\text {lat }}$ the net water lateral drainage. The amount of fluid percolating through the cell is computed as a serial method, starting at the upper layer (superficial) and proceeding downward through the cell profile to the bottom layer $Z_{1}$ (i.e., the leachate produced by 
Table 1 Model features and comparison with other hydrological models

$Y$ Yes; $N$ No; $N S$ not specified

\begin{tabular}{llllll}
\hline Features & HELP & $\begin{array}{l}\text { São } \\
\text { Mateus } \\
\text { et al. (2012) }\end{array}$ & $\begin{array}{l}\text { Lobo and } \\
\text { Tejero } \\
(2007)\end{array}$ & $\begin{array}{l}\text { De Velásquez } \\
\text { et al. } \\
(2003 \mathrm{a})\end{array}$ & $\begin{array}{l}\text { This } \\
\text { work }\end{array}$ \\
\hline Operative stage (progressive waste disposal) & $\mathrm{N}$ & $\mathrm{NS}$ & $\mathrm{Y}$ & $\mathrm{Y}$ & $\mathrm{Y}$ \\
Aftercare period & $\mathrm{Y}$ & $\mathrm{Y}$ & $\mathrm{Y}$ & $\mathrm{Y}$ & $\mathrm{Y}$ \\
Landfill discretization & $\mathrm{Y}$ & $\mathrm{Y}$ & $\mathrm{Y}$ & $\mathrm{Y}$ & $\mathrm{Y}$ \\
Vertical flow & $\mathrm{Y}$ & $\mathrm{Y}$ & $\mathrm{Y}$ & $\mathrm{Y}$ & $\mathrm{Y}$ \\
Horizontal flow & $\mathrm{Y}$ & $\mathrm{N}$ & $\mathrm{Y}$ & $\mathrm{N}$ & $\mathrm{Y}$ \\
Multilayer capping system & $\mathrm{Y}$ & $\mathrm{NS}$ & $\mathrm{Y}$ & $\mathrm{NS}$ & $\mathrm{Y}$ \\
Different waste type & $\mathrm{Y}$ & $\mathrm{Y}$ & $\mathrm{Y}$ & $\mathrm{Y}$ & $\mathrm{Y}$ \\
Waste initial moisture & $\mathrm{Y}$ & $\mathrm{Y}$ & $\mathrm{Y}$ & $\mathrm{Y}$ & $\mathrm{Y}$ \\
Potential evapotranspiration & $\mathrm{Y}$ & $\mathrm{Y}$ & $\mathrm{Y}$ & $\mathrm{Y}$ & $\mathrm{Y}$ \\
Actual evapotranspiration & $\mathrm{Y}$ & $\mathrm{Y}$ & $\mathrm{Y}$ & $\mathrm{Y}$ & $\mathrm{Y}$ \\
Surface runoff & $\mathrm{Y}$ & $\mathrm{Y}$ & $\mathrm{Y}$ & $\mathrm{Y}$ & $\mathrm{Y}$ \\
Retained/released water by cover soil & $\mathrm{Y}$ & $\mathrm{Y}$ & $\mathrm{N}$ & $\mathrm{Y}$ & $\mathrm{Y}$ \\
Water storage capacity & $\mathrm{Y}$ & $\mathrm{Y}$ & $\mathrm{Y}$ & $\mathrm{Y}$ & $\mathrm{Y}$ \\
Waste compression & $\mathrm{N}$ & $\mathrm{Y}$ & $\mathrm{Y}$ & $\mathrm{Y}$ & $\mathrm{Y}$ \\
Released water & $\mathrm{N}$ & $\mathrm{Y}$ & $\mathrm{Y}$ & $\mathrm{Y}$ & $\mathrm{Y}$ \\
Biodegradation & $\mathrm{N}$ & $\mathrm{Y}$ & $\mathrm{Y}$ & $\mathrm{N}$ & $\mathrm{Y}$ \\
Biogas production & $\mathrm{N}$ & $\mathrm{Y}$ & $\mathrm{Y}$ & $\mathrm{N}$ & $\mathrm{Y}$ \\
Wastes reduction due to biodegradation & $\mathrm{N}$ & $\mathrm{Y}$ & $\mathrm{N}$ & $\mathrm{N}$ & $\mathrm{Y}$ \\
Biotic consumption & $\mathrm{N}$ & $\mathrm{Y}$ & $\mathrm{N}$ & $\mathrm{N}$ & $\mathrm{Y}$ \\
Vapor losses & $\mathrm{N}$ & $\mathrm{Y}$ & $\mathrm{N}$ & $\mathrm{N}$ & $\mathrm{Y}$ \\
Temporal changes of waste properties & $\mathrm{N}$ & $\mathrm{Y}$ & $\mathrm{Y}$ & $\mathrm{Y}$ & $\mathrm{Y}$ \\
\hline
\end{tabular}

the cell). The total leachate production for the landfill is then calculated by summing contributions of each cell, as shown in Fig. 1.

In the next sessions, a brief description of the different terms of Eq. 1 is reported.

Incoming water

Incoming water $\left(W_{i n}\right)$ in layer $Z_{j}$ is computed in two distinct ways depending on the position of the layer within the landfill at the time $t_{i}$ :

$W_{\text {in }}\left(Z_{j}, t_{i}\right)= \begin{cases}I_{\mathrm{ef}}\left(t_{i}\right) \cdot A\left(Z_{j}\right)-W_{\text {ret, soil }}\left(Z_{j}, t_{i}\right) \quad \text { upper layer } \\ L\left(Z_{j+1}, t_{i}\right) \quad \text { intermediate layer }\end{cases}$

Namely if $Z_{j}$ is the surface layer, the incoming water, $W_{i n}$, is set equal to the surface infiltration otherwise the incoming water corresponds to the amount of leachate that leaks from the upper layer, $L\left(Z_{j+1}, t_{i}\right)$.

The effective infiltration $\left(I_{\mathrm{ef}}\right)$ through the surface layer depends on rainfall rate $(P)$, surface water runoff $(R)$ and evapotranspiration $\left(\mathrm{ET}_{r}\right)$ :

$I_{\mathrm{ef}}\left(t_{i}\right)=P\left(t_{i}\right)-R\left(t_{i}\right)-\mathrm{ET}_{r}\left(t_{i}\right)$

$W_{\text {ret,soil }}$ is the water retained by soil which may be calculated as follows:
$W_{\text {ret,soil }}\left(Z_{j}, t_{i}\right)= \begin{cases}\left(\mathrm{FC}_{\text {soil }}-\theta_{\text {soil }}\right) \cdot V_{\text {soil }}\left(Z_{j}\right) & \text { for } t_{i}=t_{\text {disposal }}\left(Z_{j}\right) \\ 0 & \text { for } t_{i}>t_{\text {disposal }}\left(Z_{j}\right)\end{cases}$

where $\mathrm{FC}_{\text {soil }}$ is the soil field capacity, $\theta_{\text {soil }}$ the initial soil moisture content and $V_{\text {soil }}$ the soil cover volume.

With reference to Eq. 4, it can be noticed that retained water by cover soil was considered relevant only for the first time step of placed layer ( $\left.t_{\text {disposal }}\right)$.

Using meteorological data on monthly bases, the model calculates surface runoff $(R)$ and actual evapotranspiration $\left(\mathrm{ET}_{r}\right)$. Namely runoff is evaluated using the SCS curve number method (USDA, Soil Conservation Service 1985) which accounts for soil cover characteristics, surface slope and initial moisture conditions. For excavated landfill, runoff is assumed negligible when the cell height is lower than the trench one. Potential evaporation is estimated by the well-known Thornthwaite's formulation, adjusted by average number of daylight hours (depending on local latitude). Actual evaporation is obtained comparing potential evaporation with the maximum amount of water available for evaporation, which is the water stored at the evaporative zone depth of surface layers. If potential evaporation is greater than water stored at that depth, only the accumulated amount will evaporate, as described by Lobo et al. (2002). 


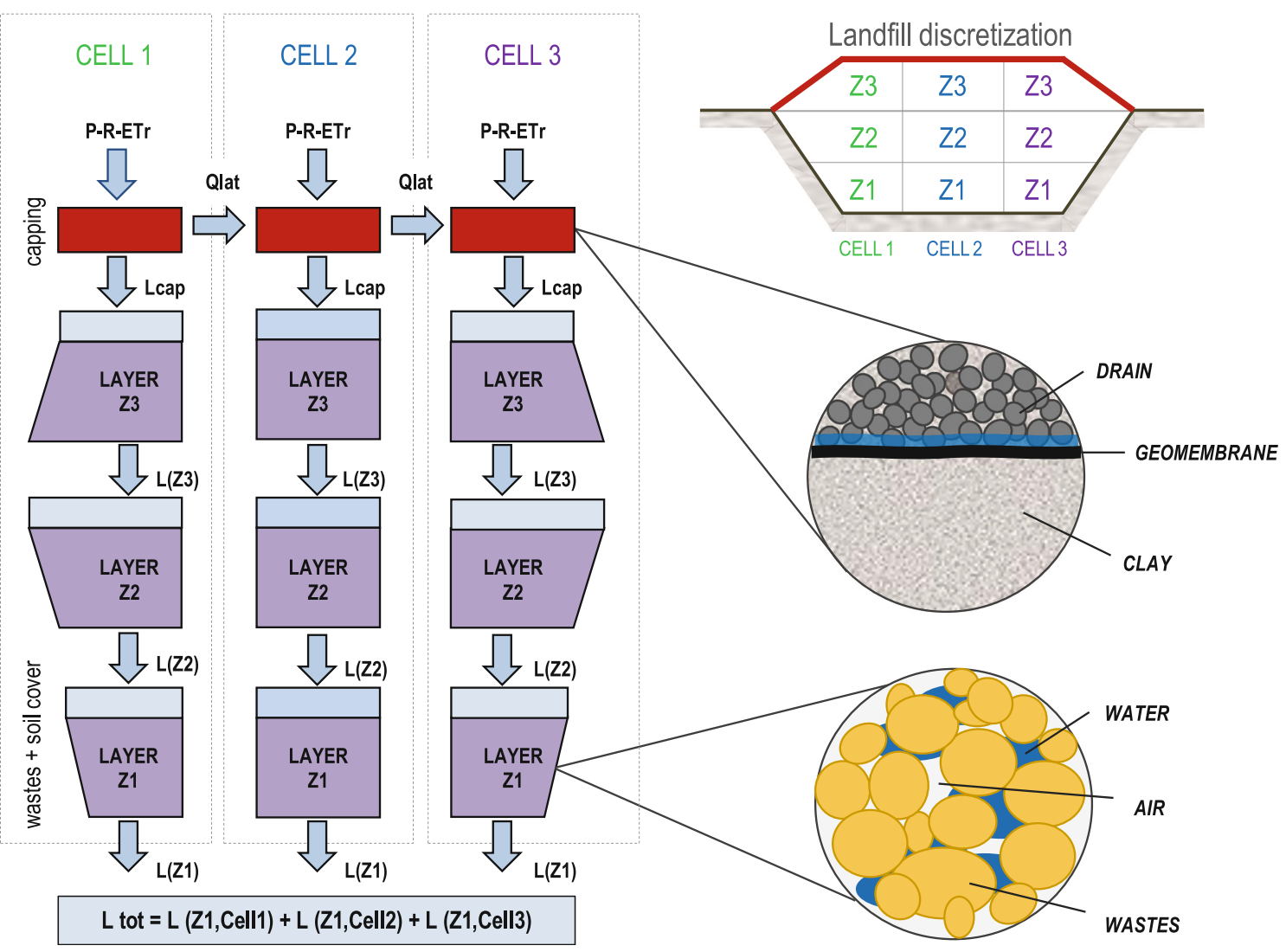

Fig. 1 Example of water balance application carried out by the model for a landfill discretized in three cells; each cell is composed by three layers of wastes and soil cover

Initial characteristics of waste

The model requires as input the waste wet density $\left(\rho_{w}\right)$ and waste composition expressed as percentage weights $\left(M_{k}\right)$ of waste fractions (organic, paper, cardboard, glass, etc.). By knowing the moisture content of each fraction, $\mathrm{w}_{\mathrm{k}}(\% \mathrm{~kg} / \mathrm{kg})$, the dry weight of waste fraction, $M_{m, k}$, the total dry weight of wastes, $M_{\mathrm{dry}, w}$, and the total moisture content $W_{w}\left(\%_{\mathrm{v} / \mathrm{v}}\right)$ can be readily obtained:

$$
\left\{\begin{array}{l}
M_{\mathrm{dry}, w}=\sum_{k} M_{m, k}=\sum_{k} M_{k} \cdot\left(1-w_{k}\right) \\
W_{w}=\left[\sum_{k}\left(w_{k} \cdot M_{k}\right)\right] \cdot \frac{\rho_{w}}{\rho_{\mathrm{H}_{2} \mathrm{O}}}
\end{array}\right.
$$

Hence, the volume of waste dry mass $V_{m}$ is:

$$
V_{m}=\sum_{k} V_{m, k}=\sum_{k} \frac{M_{m, k}}{\rho_{k}}
$$

Values of fraction densities, $\rho_{k}$, are reported by Stoltz et al. (2010).

Finally, the pores volume $\left(V_{v}\right)$ and thus initial waste porosity $(n)$ can be calculated as follows:

$$
V_{v}=\frac{M_{\mathrm{dry}, w}+M_{\mathrm{H}_{2} \mathrm{O}}}{\rho_{w}}-V_{m} ; \quad n=\frac{V_{v}}{V_{m}+V_{v}}
$$

Released and retained water by wastes

Changes in water content $(\Delta U)$ are due to temporal variation of hydraulic retention capacity of waste layers as well as to the waste water content in excess/defect compared to the retention capacity $\left(\mathrm{CS}_{\max }\right)$ :

$\Delta U\left(Z_{j}, t_{i}\right)=W_{w}\left(Z_{j}, t_{i}\right)-\mathrm{CS}_{\max }\left(Z_{j}, t_{i}\right)$

where $W_{w}$ is the initial water content of waste at the time $t_{i}$ :

$W_{w}\left(Z_{j}, t_{i}\right)=\left\{\begin{array}{c}W_{\text {res }}\left(Z_{j}, t_{i-1}\right) \text { unsatured } \\ C_{\max }\left(Z_{j}, t_{i-1}\right) \text { saturated }\end{array}\right.$

$W_{\text {res }}$ is the residual water content at the previous time $t_{i-1}$ which is equal to the final retention capacity $\left(\mathrm{CS}_{\max }\right)$ if the layer has become saturated. Otherwise, leaching does not occur and water is stored within wastes and $W_{\text {res }}$ is computed as:

$$
\begin{aligned}
W_{\text {res }}\left(Z_{j}, t_{i}\right)= & W_{\text {in }}\left(Z_{j}, t_{i}\right)-W_{\text {bio }}\left(Z_{j}, t_{i}\right)-W_{\text {vap }}\left(Z_{j}, t_{i}\right) \\
& +W_{\text {res }}\left(Z_{j}, t_{i-1}\right)
\end{aligned}
$$


For $t_{i}=t_{\text {disposal }}\left(Z_{j}\right), W_{\text {res }}\left(Z_{j}, t_{i-1}\right)$ is equal to the initial moisture content of the layer.

The released $\left(W_{\text {rel }}\right)$ and retained water $\left(W_{\text {ret }}\right)$ reported in Eq. 1 is calculated from Eq. 8 as follows:

$$
\begin{aligned}
& W_{\text {rel }}\left(Z_{j}, t_{i}\right)=\Delta U\left(Z_{j}, t_{i}\right) ; W_{\text {ret }}\left(Z_{j}, t_{i}\right)=0 \text { for } \Delta U\left(Z_{j}, t_{i}\right)>0 \\
& W_{\text {rel }}\left(Z_{j}, t_{i}\right)=0 ; W_{\text {ret }}\left(Z_{j}, t_{i}\right)=\left|\Delta U\left(Z_{j}, t_{i}\right)\right| \text { for } \Delta U\left(Z_{j}, t_{i}\right) \leq 0
\end{aligned}
$$

The water retention capacity of each layer, $\operatorname{CS}_{\max }\left(Z_{j}\right)$, at the time $t_{i}$ can be estimated as:

$\mathrm{CS}_{\max }\left(Z_{j}, t_{i}\right)=\mathrm{FC}_{w}\left(Z_{j}, t_{i}\right) \cdot V_{w}\left(Z_{j}, t_{i}\right)$

where $V_{w}\left(Z_{j}, t_{i}\right)$ is the waste volume, and $\mathrm{FC}_{w}\left(Z_{j}, t_{i}\right)$ the waste field capacity both varying with time as a function of the pressure exerted by the upper layers (Lobo et al. 2002) and the biodegradation processes. In this work, the waste field capacity is calculated using the expression reported by Lobo et al. (2002) with a monotonous descending trend (i.e., assuming that water retention capacity and fluid flow are controlled by the maximum applied stress):

$\mathrm{FC}_{w}\left(Z_{j}, t_{i}\right)=\mathrm{FC}_{w, 0}-\left(\mathrm{FC}_{w, 0}-\mathrm{FC}_{w, \lim }\right) \cdot \frac{\sigma_{s}\left(Z_{j}, t_{i}\right)}{\mathrm{CC}_{c}+\sigma_{s}\left(Z_{j}, t_{i}\right)}$

where $\mathrm{FC}_{w, 0}$ is the initial waste field capacity, $\mathrm{FC}_{w, \lim }$ is the waste field capacity corresponding to the infinite pressure on the layer (assumed equal to the wilting point of waste) and $\mathrm{CC}_{c}$ is a constant that defines the field capacity variation with the mean pressure on the waste $\sigma_{s}$ (the higher is $\mathrm{CC}_{c}$, the lower is the refusal compressibility). Values of constant $\mathrm{CC}_{c}$ proposed by authors range from 5,000 to $30,000 \mathrm{~kg} / \mathrm{m}^{2}$ (Lobo et al. 2002; Sirini et al. 2010), but it is closely related to the nature and composition of wastes.

It is worth noting that the previous expression (Eq. 13), which is in line with other modeling approaches (e.g., São Mateus et al. 2012, Lobo et al. 2002, Lobo and Tejero 2007), assumes that the waste field capacity decreases if the mean pressure on the waste, $\sigma_{s}$, increases because of the materials redistribution which entails voids reduction in number and size. This behavior was also observed in some laboratory tests carried out by Powrie et al. (2000), De Velásquez et al. (2003b), Olivier and Gourc (2007) and Wu et al. (2012). However, it should be considered that this aspect is still under discussion. For instance, some authors (e.g., Münnich et al. 2009; Stoltz et al. 2010) have observed in their experiments an opposite trend with an increase in the volume of retained water with higher density due to the increase in capillary forces prevailing over the reduction of total pore volume (Münnich et al. 2009). However, Münnich et al. (2009) and Stoltz et al. (2010) pointed out that measurement of waste field capacity may be affected by the method used for the determination and by other factors such as waste composition, emplacement density, drainage time and the equilibrium between sample and moisture.

The mean pressure $\sigma_{s}$ applied on each layer is calculated at the average height of the layer, and it depends on the landfill's profile, waste residual dry mass and water content at the time $t_{i}$ :

$$
\begin{aligned}
\sigma_{s}\left(Z_{j}, t_{i}\right)= & \frac{0.5\left[M_{\mathrm{H}_{2} \mathrm{O}}\left(Z_{j}, t_{i}\right)+M_{\mathrm{dry}, w}\left(Z_{j}, t_{i}\right)\right]+M_{\mathrm{soil}}\left(Z_{j}, t_{i}\right)}{A\left(Z_{j}\right)} \\
& +\sum_{k=1}^{N-j} \frac{M_{\mathrm{tot}}\left(Z_{j+k}, t_{i}\right)}{A\left(Z_{j+k}\right)}
\end{aligned}
$$

where $M_{\mathrm{dry}, w}$ is the waste dry mass, which decreases with the degradation process development; $\mathrm{M}_{\mathrm{H}_{2} \mathrm{O}}$ is the water mass contained in the layer at time $t_{i}, M_{\text {soil }}$ is the mass of the intermediate soil cover and the second term on the right side is the total mass of the upper layers at time $t_{i}$.

Water retention capacity of layer $\left(\mathrm{CS}_{\max }\right)$ at the time $t_{i}$ is related to waste volume $V_{w}$, influenced by compression phenomena which reduce pores volume $\left(V_{v}\right)$, as well as by the evolving biological process which reduces the residual dry volume of waste $\left(V_{m}\right)$ :

$$
\begin{aligned}
V_{w}\left(Z_{j}, t_{i}\right) & =V_{v}\left(Z_{j}, t_{i}\right)+V_{m}\left(Z_{j}, t_{i}\right) \\
& =n\left(Z_{j}, t_{i}\right) \frac{V_{m}\left(Z_{j}, t_{i}\right)}{\left[1-n\left(Z_{j}, t_{i}\right)\right]}+V_{m}\left(Z_{j}, t_{i}\right)
\end{aligned}
$$

The degraded waste volume, $V_{\mathrm{deg}}\left(Z_{j}, t_{i}\right)$, can be estimated by applying a triangular pattern (Tchobanoglous et al. 1993) as a function of the readily biodegradable (RBOF) and slowly biodegradable organic fraction (SBOF) consumption:

$$
\begin{aligned}
V_{m}\left(Z_{j}, t_{i}\right) & =V_{m}\left(Z_{j}, t_{i-1}\right)-V_{\mathrm{deg}}\left(Z_{j}, t_{i}\right) \\
& =\sum_{k} \frac{\left[M_{m, k}\left(Z_{j}, t_{i-1}\right)-M_{\mathrm{deg}, k}\left(Z_{j}, t_{i}\right)\right]}{\rho_{k}}
\end{aligned}
$$

where $M_{m, k}$ and $\rho_{k}$ are the dry mass and density of each waste fraction $k$, respectively.

Biotic consumption and vapor losses

Water losses as biotic consumption and vapor are closely linked to the gas produced by waste. Biogas generation rate depends on several factors (Bicheldey and Latushkina 2010; Rawat and Ramanathan 2011; Behera et al. 2010; Machado et al. 2009), such as waste composition and density, water availability and others site-specific conditions (e.g., temperature, $\mathrm{pH}$, nutrients). In this work, gas generation is assessed using the simple anaerobic model proposed by Tchobanoglous et al. (1993). The quantity of landfill gas produced by waste is calculated starting from elemental composition of biodegradable fraction $\mathrm{RBOF}$ and SBOF: 
$\left\{\begin{array}{l}\mathrm{RBOF}: \mathrm{C}_{a} \mathrm{H}_{b} \mathrm{O}_{c} N_{d}+\alpha^{\mathrm{RBOF}} \cdot \mathrm{H}_{2} \mathrm{O} \rightarrow \beta \mathrm{CH}_{4}+\gamma \mathrm{CO}_{2}+\delta \mathrm{NH}_{3} \\ \text { SBOF }: \mathrm{C}_{a^{\prime}} \mathrm{H}_{b^{\prime}} \mathrm{O}_{c^{\prime}} \mathrm{N}_{d^{\prime}}+\alpha^{\mathrm{SBOF}} \cdot \mathrm{H}_{2} \mathrm{O} \rightarrow \beta^{\prime} \mathrm{CH}_{4}+\gamma^{\prime} \mathrm{CO}_{2}+\delta^{\prime} \mathrm{NH}_{3}\end{array}\right.$

Where $\mathrm{C}_{\mathrm{a}} \mathrm{H}_{\mathrm{b}} \mathrm{O}_{\mathrm{c}} \mathrm{N}_{\mathrm{d}}$ is the molecular formula of RBOF and $\mathrm{SBOF}$ estimated from waste composition.

By applying balance for each element $(\mathrm{C}, \mathrm{H}, \mathrm{O}$ and $\mathrm{N})$, the quantity of water consumption $(\alpha)$ and gas composition ( $\beta$ and $\gamma$ for methane and carbon dioxide, respectively) can be determined:
The water losses ( $\left.W_{\text {vap }}\right)$ as vapor during gas extraction is calculated by assuming gas saturation (i.e., $u_{r}=1$ ):

$$
\begin{aligned}
W_{\text {vap }}\left(Z_{j}, t_{i}\right)= & \left(\frac{P M_{\mathrm{H}_{2} \mathrm{O}}}{R_{g} \cdot T \cdot \rho_{\mathrm{H}_{2} \mathrm{O}}} \cdot u_{r} \cdot P_{v, \text { sat }}\right) \\
& \cdot\left(Q_{\text {biogas }}^{\mathrm{RBOF}}\left(Z_{j}, t_{i}\right)+Q_{\text {biogas }}^{\mathrm{SBOF}}\left(Z_{j}, t_{i}\right)\right)
\end{aligned}
$$

where $\mathrm{PM}_{\mathrm{H}_{2} \mathrm{O}}$ is the water molecular mass $(\mathrm{g} / \mathrm{mol}), R_{g}$ the universal gas constant $(8,314 \mathrm{j} / \mathrm{molK}), u_{r}$ the relative humidity of the gaseous mixture and $P_{v \text {,sat }}$ the saturated vapor pressure. The temperature $(\mathrm{T})$ is assumed equal to

$\left\{\begin{array}{l}\mathrm{RBOF}: \alpha^{\mathrm{RBOF}}=\frac{4 a-b-2 c+3 d}{4} ; \beta=\frac{4 a+b-2 c-3 d}{8} ; \gamma=\frac{4 a-b+2 c+3 d}{8} \\ \mathrm{SBOF}: \alpha^{\mathrm{SBOF}}=\frac{4 a^{\prime}-b^{\prime}-2 c^{\prime}+3 d^{\prime}}{4} ; \beta^{\prime}=\frac{4 a^{\prime}+b^{\prime}-2 c^{\prime}-3 d^{\prime}}{8} ; \gamma^{\prime}=\frac{4 a^{\prime}-b^{\prime}+2 c^{\prime}+3 d^{\prime}}{8}\end{array}\right.$

The moles of methane $(\beta)$ and carbon oxide $(\gamma)$ are converted in volumes using ideal gas equation, and the total amount of landfill gas $\left(V_{\text {biogas,tot }}\right)$ is computed as the sum of methane and carbon dioxide volumes:

$$
\begin{aligned}
V_{\text {biogas,tot }}^{\mathrm{RBOF}} & =(\beta+\gamma) \cdot\left(\frac{R_{g} T}{p} \frac{\%_{M} \mathrm{RBOF}}{\mathrm{PM}^{\mathrm{RBOF}}} M_{w}\right) \\
V_{\text {biogas,tot }}^{\mathrm{SBOF}} & =\left(\beta^{\prime}+\gamma^{\prime}\right) \cdot\left(\frac{R_{g} T}{p} \frac{\%_{M} \mathrm{SBOF}}{P M^{\mathrm{SBOF}}} M_{w}\right)
\end{aligned}
$$

where $\%_{M}$ is the percentage of biodegradable mass, $M_{w}$ the initial waste mass and PM the molecular mass.

To obtain the temporal trend of biogas production $\left(Q_{\text {biogas }}^{f}\right)$, the decomposition time $\left(t_{\text {deg }}^{f}\right)$ and the peak time of gas production $\left(t_{\text {peak }}^{f}\right)$ for organic fraction $f(\mathrm{RBOF}$ or SBOF) must be defined:

$Q_{\text {biogas }}^{f}\left(Z_{j}, t_{i}\right)=\left\{\begin{array}{l}\frac{2 V_{\text {biogas,tot }}^{f}}{t_{\text {deg }}^{f}} \cdot \frac{t_{i}}{t_{\text {peak }}^{f}} \quad \text { for } t_{i} \leq t_{\text {peak }}^{f} \\ \frac{2 V_{\text {biogas,tot }}^{f}}{t_{\text {deg }}^{f}} \cdot \frac{t_{\text {deg }}^{f}-t_{i}}{t_{\text {deg }}^{f}-t_{\text {peak }}^{f}} \text { for } t_{i}>t_{\text {peak }}^{f}\end{array}\right.$

Thus, water biotic consumption is calculated as:

$$
\begin{aligned}
W_{\text {bio }}\left(Z_{j}, t_{i}\right)= & \alpha^{\mathrm{RBOF}} \cdot \frac{\mathrm{PM}_{\mathrm{H}_{2} \mathrm{O}} \cdot \%_{M} \mathrm{RBOF} \cdot M_{w}}{\mathrm{PM}_{\mathrm{RBOF}} \cdot \rho_{\mathrm{H}_{2} \mathrm{O}}} \cdot \frac{Q_{\text {biogas }}^{\mathrm{RBOF}}\left(Z_{j}, t_{i}\right)}{V_{\text {biogas,tot }}^{\mathrm{RBOF}}} \\
& +\alpha^{\mathrm{SBOF}} \cdot \frac{\mathrm{PM}_{\mathrm{H}_{2} \mathrm{O}} \cdot \%_{M} \mathrm{SBOF} \cdot M_{w}}{\mathrm{PM}_{\mathrm{SBOF}} \cdot \rho_{\mathrm{H}_{2} \mathrm{O}}} \cdot \frac{Q_{\text {biogas }}^{\mathrm{SBOF}}\left(Z_{j}, t_{i}\right)}{V_{\text {biogas }, \text { tot }}^{\mathrm{SBOF}}}
\end{aligned}
$$

$35^{\circ} \mathrm{C}$ which corresponds roughly with the conditions prevailing inside the landfill, where temperatures between 22 and $46{ }^{\circ} \mathrm{C}$ were measured (Fellner et al. 2009).

It is worth noting that the expressions used for determining gas production allow to quantify biotic consumption and vapor losses while keeping a simplified approach which requires a quite limited number of input data (i.e., waste composition and decomposition times $t_{\text {deg }}, t_{\text {peak }}$ ). However, other more detailed models, which provide a more realistic representation of the decay of organic matter in landfill, are available (e.g., Gawande et al. 2010; Vavilin 2010; Zacharof and Butler 2004; White and Beaven 2013).

Aftercare period

The aftercare period of a landfill starts when the final cover (capping) is realized. In order to minimize water infiltration and thus leachate emissions, a vegetative cover is usually established to favor evapotranspiration, and a layer of clay is lain to promote overland flow (Laner et al. 2011; Schnabel et al. 2012; Venkatraman et al. 2011). In addition, the clay can possibly be protected through geosynthetic sheets. The water balance for capping is computed considering the resistance offered to motion by each layer of the cover and assuming that the water flux is bound by the lower permeable layer:

$I_{\mathrm{ef}}\left(t_{i}\right) \cdot A\left(Z_{j}\right)+Q_{\mathrm{lat}}\left(Z_{j}, t_{i}\right)=Q_{u}\left(Z_{j}, t_{i}\right)+Q_{\mathrm{in}}\left(Z_{j}, t_{i}\right)$

where $I_{\mathrm{ef}}$ is the effective infiltration, $Q_{\text {lat }}$ the entering water in $Z_{j}$ coming from the adjacent layer, $Q_{u}$ the flow drained by the layer and $Q_{\text {in }}$ the water flow infiltrating in waste. 
Incoming lateral water $\left(Q_{\text {lat }}\right)$ in $Z_{j}$ corresponds to drained flow coming from the adjacent layer $\left(Q_{u, \mathrm{ad}}\right)$ :

$Q_{\text {lat }}\left(\mathrm{Z}_{j}, \mathrm{t}_{i}\right)=Q_{\mathrm{u}, \mathrm{ad}}\left(t_{i}\right)$

Lateral water flow $\left(Q_{u}\right)$ that moves away without infiltrating in the layer is computed through Darcy's equation as a function of the distance between the cell and the water collection system $\left(D_{c}\right)$, the hydraulic conductivity of drain $\left(K_{d}\right)$, the water head $(\Delta H)$ and the cell size along orthogonal direction to the main direction of flow $(B)$ :

$\mathrm{Q}_{u}\left(\mathrm{Z}_{j}, t_{i}\right)=K_{d} \cdot \frac{B\left(\mathrm{Z}_{j}, t_{i}\right)}{D_{c}\left(\mathrm{Z}_{j}, t_{i}\right)} \cdot \frac{\Delta H^{2}\left(\mathrm{Z}_{j}, t_{i}\right)}{2}$ liner construction has been done. A flaw density of 30 defects per hectare or more is recommended if quality assurance is limited to spot checks or when environmental difficulties have been encountered during installation. To simplify computation, it is neglected geosynthetic time-dependent deterioration due to aging or external elements, such as chemicals, temperature and mechanical actions that can create sheet flaws or increase the size of existing flaw, resulting in higher infiltration rates within the landfill.

The water head, $\Delta H$, can be calculated by rearranging Eq. 23 with Eqs. 24-27:

$\Delta H\left(\mathrm{Z}_{j}, \mathrm{t}_{i}\right)=\frac{-\left(\frac{K_{x}}{s_{x}} \cdot A_{x}+\xi\right)+\sqrt{\left(\frac{K_{x}}{s_{x}} A_{x}+\xi\right)^{2}+2 \cdot B \cdot \frac{K_{d}}{D_{c}} \cdot\left(I_{e f}\left(t_{i}\right) \cdot A\left(Z_{j}\right)+Q_{l a t}\left(t_{i}\right)-K_{x} \cdot A_{x}\right)}}{B \cdot \frac{K_{d}}{D_{c}}}$

Water flow, $Q_{\text {in }}$, that infiltrates in the wastes layer (i.e., no geosynthetic sheet) is calculated through Darcy's equation, and it depends on the hydraulic conductivity of clay $\left(K_{c}\right)$ on the water head $(\Delta H)$ and the clay thickness $\left(s_{c}\right)$ :

$\mathrm{Q}_{\text {in }, c}\left(Z_{j}, t_{i}\right)=K_{c} \cdot \frac{\Delta H\left(Z_{j}, t_{i}\right)+s_{c}}{s_{c}} \cdot \mathrm{A}\left(Z_{j}\right)$

If geosynthetic sheets are lain on clay layer, the former leads to the maximum rate of water infiltration in wastes cluster. In this case, the incoming water term $\left(Q_{\text {in }}\right)$ should be modified accounting for both diffusive flux through geosynthetic material and the flow through pinholes and installation defects of geosynthetic sheet:

$$
\begin{aligned}
Q_{\text {in }, g}\left(\mathrm{Z}_{j}, t_{i}\right)= & K_{g} \cdot A_{g}\left(Z_{j}, t_{i}\right) \cdot \frac{\Delta H\left(Z_{j}, t_{i}\right)+s_{g}}{s_{g}} \\
& +K_{c} \cdot \eta \cdot A_{g}\left(Z_{j}, t_{i}\right) \cdot \frac{\Delta H\left(Z_{j}, t_{i}\right)}{s_{g}}
\end{aligned}
$$

where $K_{g}$ is geosynthetic hydraulic conductivity, $A_{g}$ the effective area of geosynthetic (computed through the percentage of cracked of the geosynthetic sheet $\eta), s_{g}$ the sheet thickness, and $d_{f}$ and $A_{f}$ are the diameter and area of pinholes, respectively. Giroud and Bonaparte (1989) recommend using a defect area of $1 \mathrm{~cm}^{2}$ for conservative reasons and adopting a defect density of 3-5 defects per hectare, if an intensive quality control monitoring during where:

$\left\{\begin{array}{l}\xi=0 ; K_{x}=K_{c} ; \mathrm{s}_{x}=s_{c} \text { no synthetic layer } \\ \xi=K_{c} \cdot \eta \cdot A_{g}\left(Z_{j}, t_{i}\right) / s_{g} ; K_{x}=K_{g} ; \mathrm{s}_{x}=s_{g} \text { synthetic layer }\end{array}\right.$

It is worth noting that Eq. 28 can be also used to estimate the amount of water which leaks through the bottom liner system simply replacing $I_{\mathrm{ef}}\left(t_{\mathrm{i}}\right)$ with $L\left(Z_{1}, t_{i}\right)$ and assuming $D_{c}$ equal to the effective distance between leachate pipes accounting for the slope.

\section{Results and discussion}

Influence of biodegradation and compression on leachate production

In order to better understand how biodegradation and compression processes may affect the expected leachate production, several simulations, assuming different municipal solid waste (MSW) properties, were carried out (see Table 2). Namely, 4 tests assuming saturated (Test 1 and 3) or unsaturated initial wastes conditions (Test 2 and 4) were performed. In each Test, the constant of waste compressibility $(\mathrm{CC} c)$ has been progressively modified to assess the influence of waste consolidation processes on leachate prediction. Finally, the contribution of the different processes on the overall leachate production is highlighted by 
Table 2 Parameters' values of landfill scheme assumed in the simulations of the different hypothetical scenarios (Tests 1 , $2,3,4)$

acp aftercare period

${ }^{\text {a }}$ Parameters modified in the different tests

\begin{tabular}{|c|c|c|c|c|}
\hline Parameters & Test 1 & Test 2 & Test 3 & Test 4 \\
\hline Landfill area (ha) & 1 & 1 & 1 & 1 \\
\hline Operative stage (year) & 1 & 1 & 1 & 1 \\
\hline Post-operative stage (year) & 10 & 10 & 10 & 10 \\
\hline Number of cells & 1 & 1 & 1 & 1 \\
\hline Number of layers & 1 & 1 & 1 & 1 \\
\hline Total layers & 1 & 1 & 1 & 1 \\
\hline Time of disposal & 1 & 1 & 1 & 1 \\
\hline Layer thickness (m) & 3 & 3 & 3 & 3 \\
\hline Intermediate cover soil & None & None & None & None \\
\hline Waste type & MSW & MSW & MSW & MSW \\
\hline Biodegradation $^{\mathrm{a}}$ & Yes & Yes & No & No \\
\hline Total porosity $\left(\%_{\mathrm{v} / \mathrm{v}}\right)$ & 60 & 60 & 60 & 60 \\
\hline Field capacity $\left(\%_{\mathrm{v} / \mathrm{v}}\right)^{\mathrm{a}}$ & 25 & 35 & 25 & 35 \\
\hline Waste initial moisture $\left(\%_{\mathrm{v} / \mathrm{v}}\right)$ & 25 & 25 & 25 & 25 \\
\hline Waste density $\left(\mathrm{kg} / \mathrm{m}^{3}\right)$ & 811 & 811 & 811 & 811 \\
\hline Wilting point $\left(\%_{\mathrm{v} / \mathrm{v}}\right)$ & 7.7 & 7.7 & 7.7 & 7.7 \\
\hline Compressibility constant $\left(\mathrm{kg} / \mathrm{m}^{2}\right)^{\mathrm{a}}$ & $\begin{array}{l}5000 / 30000 / \\
10^{9}\end{array}$ & $\begin{array}{l}5000 / 30000 / \\
10^{9}\end{array}$ & $\begin{array}{l}5000 / 30000 / \\
10^{9}\end{array}$ & $\begin{array}{l}5000 / 30000 / \\
10^{9}\end{array}$ \\
\hline Rainfall (mm) & 965 & 965 & 965 & 965 \\
\hline Evapotranspiration (mm) & 420 & 420 & 420 & 420 \\
\hline Evapotranspiration acp (mm) & 465 & 465 & 465 & 465 \\
\hline Runoff (mm) & 170 & 170 & 170 & 170 \\
\hline Runoff acp (mm) & 410 & 410 & 410 & 410 \\
\hline
\end{tabular}

comparing the model results with those obtained applying the HELP model which neglects both biodegradation and compression.

It is worth noting that the different simulations were performed assuming constant values of runoff and evapotranspiration (see Table 2) to better understand how biodegradation and compression processes may affect the final results of the model.

Figure 2 shows the annual leachate production predicted by the developed model for the condition given in Test 1 (Fig. 2a), Test 2 (Fig. 2b), Test 3 (Fig. 2c) and Test 4 (Fig. 2d). For reference, the results obtained by applying the HELP model with the same input data are also reported (dashed line). With reference to these figures, it can be noticed that leachate volumes predicted by the developed model are generally higher than those returned by HELP. Namely, the main differences are observed in the early part of the simulation (first and second year), corresponding to the operative stage of landfill management and are more evident for unsaturated waste (Fig. 2b, d) and for high compressibility (HC); whereas, when wastes have reached the stability condition during aftercare period, the two models return similar values. The differences observed in the first years of simulation can be mainly attributed to the waste compression effect which is neglected in the HELP model. In fact, the wastes are initially subjected to a rapid compression as a consequence of their own weight and of final cover system (which is assumed to be realized at the second year of simulations) resulting in a water release.

Figure 2 also shows that even in the case of almost incompressible wastes (see $\mathrm{NC}$ in Fig. 2a-d) the two models provide quite different results. This can be attributed to the difficulty of applying HELP for a landfill in evolution. In fact, in order to reproduce the filling operation of the active landfill, two different simulations with HELP were carried out: one (first year) corresponding to the disposal of waste layer and the other one (2nd-10th year of the simulation) simulating the landfill aftercare period. Moreover, as pointed out by the State of Ohio EPA (2005), for short simulations (less than 5 years), the values returned by HELP may be unrepresentative since it is possible that flow equilibrium has not been reached. Schroeder et al. (1994) also indicated that HELP tends to overestimate the water storage in waste during the early part of simulation and overestimates the time required for leachate to be generated, causing an underestimation of the amount of predicted leachate.

In the years following the third (i.e., when wastes reach stability condition during aftercare period), the two models approach each other (see Fig. 2). However, slight differences in the expected leachate production are still observed (see Fig. 2a-b). These results, which are more evident for 
Fig. 2 Annual trend of leachate produced within the landfill for the different hypothetical scenarios simulated in Test 1 (a), 2(b), 3(c), 4(d). For reference, the results obtained with HELP are also reported. $H C=$ high compressibility $\left(\mathrm{CC}_{\mathrm{c}}=5000 \mathrm{~kg} / \mathrm{m}^{2}\right)$;

$L C=$ low compressibility $\left(\mathrm{CC}_{\mathrm{c}}=30000 \mathrm{~kg} / \mathrm{m}^{2}\right)$;

$N C=$ incompressible

$\left(\mathrm{CC}_{\mathrm{c}}=10^{9} \mathrm{~kg} / \mathrm{m}^{2}\right)$ (a)

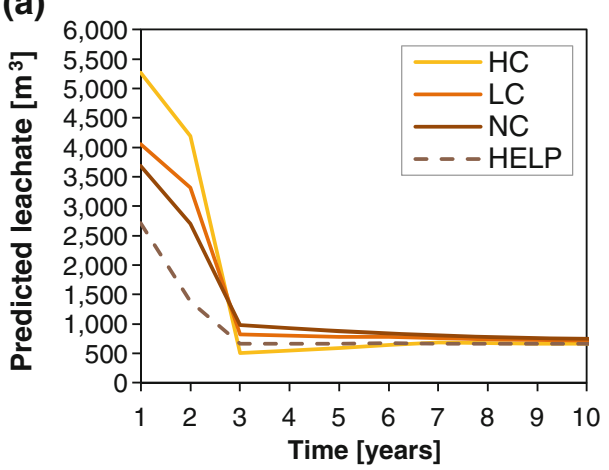

(c)

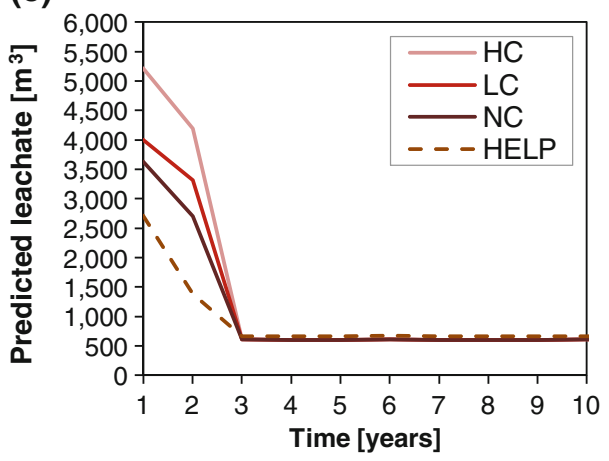

(b)

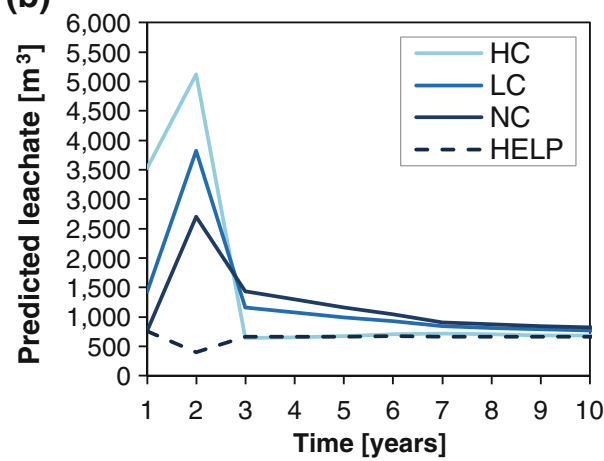

(d)

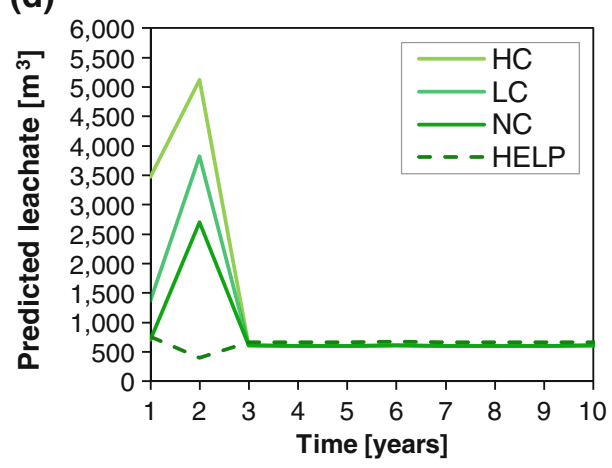

unsaturated waste (Fig. 2b), are presumably due to the fact that HELP neglects biodegradation. In fact, biodegradation processes lead, on the one hand, to a water consumption to sustain the oxide-reductive reactions and, on the other hand, to a volume reduction in organic matter and consequently of water retention capacity. This is in line with the results obtained by Powrie et al. (2000) which have observed that gas generation reduces the volume of water that can be hold by wastes.

Application of the developed model to a municipal solid waste landfill

In this section, an application of the developed model and of HELP to a real landfill is presented. The considered landfill is located in the center of Italy, and it is currently in operative management stage, since wastes disposal started in 2009. The landfill, which covers an area ranging from about 1.6-2.5 hectares, receives solid wastes from surrounding areas. Namely, MSW wastes are disposed on an excavated trench, using high-density polyethylene (HDPE) sheets as daily covering to reduce water infiltration. This scenario was simulated assuming a single cell composed of four vertical annual layers $\left(Z_{1}, Z_{2}, Z_{3}\right.$ and $\left.Z_{4}\right)$ whose characteristics are reported in Tables 3,4 . Wastes composition (Fig. 3) was provided by the landfill managing company.

Table 3 summarizes the main parameters used for model simulations, which were obtained after a preliminary
Table 3 Main parameters used in model simulations for the case study

\begin{tabular}{lll}
\hline Parameter & Value & Unit \\
\hline Wet waste density & 908 & $\mathrm{~kg} / \mathrm{m}^{3}$ \\
Initial waste moisture & 29.1 & $\% \mathrm{v} / \mathrm{v}$ \\
Waste total porosity & 49 & $\% \mathrm{v} / \mathrm{v}$ \\
Waste field capacity & 34 & $\% \mathrm{v} / \mathrm{v}$ \\
Wilting point of waste & 7.7 & $\% \mathrm{v} / \mathrm{v}$ \\
Hydraulic conductivity of waste ${ }^{\mathrm{a}}$ & 86.4 & $\mathrm{~cm} / \mathrm{day}$ \\
Compressibility constant & 10,000 & $\mathrm{~kg} / \mathrm{m}^{2}$ \\
RBOF decomposition time & 5 & year \\
RBOF gas production peak time & 1 & year \\
SBOF decomposition time & 15 & year \\
SBOF gas production peak time & 5 & year \\
Percentage of conversion & 55 & $\%$ \\
Evaporative zone depth & 0.2 & $\mathrm{~m}$ \\
Trench height & 22 & $\mathrm{~m}$ \\
\hline
\end{tabular}

${ }^{\text {a }}$ Hydraulic conductivity was used only for HELP simulations, and it was set equal to the default value

b Provided by landfill managing company

calibration process. Values of hydrological parameters are in line with those reported by Shariatmadari et al. (2010), Oni and Okunade (2009) and Olivier and Gourc (2007).

The bottom liner system of the landfill was simulated assuming: a drainage layer of sand (permeability of $5.8 \times 10^{-3} \mathrm{~cm} / \mathrm{s}$ and thickness of $0.3 \mathrm{~m}$ ), an HDPE geomembrane with a density of 2 defects per hectare and 2 
Table 4 Annual and cumulative values of leachate predicted by the developed model and HELP and data measured in the collection system during the period of January 2009-October 2012

\begin{tabular}{|c|c|c|c|c|c|c|c|}
\hline \multirow[t]{2}{*}{ Years } & \multirow{2}{*}{$\begin{array}{l}\text { Wastes initial } \\
\text { height }(\mathrm{m})\end{array}$} & \multirow[t]{2}{*}{$\operatorname{Area}^{\mathrm{a}}\left(\mathrm{m}^{2}\right)$} & \multirow{2}{*}{$\begin{array}{l}\text { Disposed } \\
\text { wastes }^{\mathrm{a}} \text { (ton) }\end{array}$} & \multirow{2}{*}{$\begin{array}{l}\text { Rainfall }^{\mathrm{b}} \\
(\mathrm{mm})\end{array}$} & \multicolumn{3}{|c|}{ Annual leachate volume $\left(\mathrm{m}^{3}\right)$} \\
\hline & & & & & LWB model & HELP model & Measured values $^{\mathrm{a}}$ \\
\hline 2009 & 11.3 & 15,694 & 128,131 & 776 & 23,296 & 6,104 & 23,413 \\
\hline 2010 & 7.4 & 21,000 & 122,755 & $758^{(\mathrm{c})}$ & 30,109 & 6,576 & 30,527 \\
\hline 2011 & 5.3 & 23,500 & 109,763 & $717^{(\mathrm{c})}$ & 30,031 & 8,270 & 30,292 \\
\hline $2012^{\mathrm{d}}$ & 3.6 & 25,000 & 82,635 & 644 & 19,477 & 2,005 & 12,214 \\
\hline TOTAL & 27.6 & 25,000 & 443,283 & 2,895 & 102,914 & 22,955 & 96,447 \\
\hline
\end{tabular}

The predicted leachate volumes are referred to the volumes expected in the bottom lateral drainage net

${ }^{a}$ Values provided by managing company

b Values from in situ weather station

c Data integrated from nearby weather station

d January-October 2012

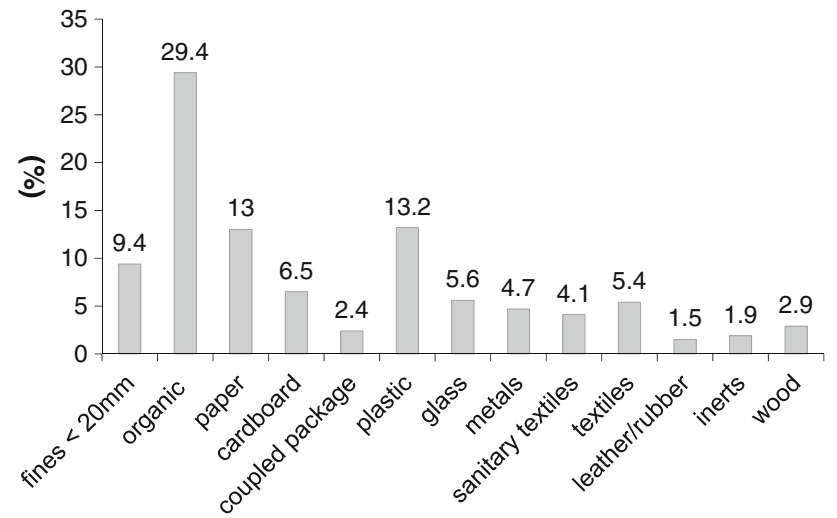

Fig. 3 MSW composition provided by the landfill managing company

pinholes per hectare and a clay layer (permeability of $10^{-5} \mathrm{~cm} / \mathrm{s}$ and thickness of $1 \mathrm{~m}$ ) below the geomembrane.

Finally, the monthly average values of precipitation and temperature used in both models have been collected from in situ weather station; however, some malfunctions were detected for periods Sept10-Feb11 and Jul11-Oct11. For these months, values of rainfall were integrated with those measured by a nearby station.

Table 4 reports a comparison of the annual and cumulative leachate volumes predicted by the developed model and by HELP, with the landfill measurements of the leachate flow in the final collection pipe during the period of January 2009 to October 2012. The values reported in this table are referred to the leachate in the drainage layer where the perforated pipes are embedded, since in both models leakages through bottom liner were negligible (always lower than $0.1 \%$ of the amount of leachate collected in the bottom lateral drainage net). With reference to Table 4, it can be noticed that the leachate production obtained by the developed model is close to the available field data, whereas the HELP model tends to underestimate the leachate volumes with errors up to $80 \%$.

The values provided by HELP can be presumably due on the one hand to the low hydraulic conductivity assumed for refusal (resulting in greater evaporation losses and thus a lower infiltration rate) and on the other hand, to the different simulations carried out in order to reproduce progressive wastes disposal (leading to errors related to computation discontinuity and convergence). More specifically, the landfill operational period was simulated with HELP performing four distinct runs, each one lasting for 25 years, and selecting the annual leachate values (reported in Table 4) which match with the condition of low and steady change in water storage (State of Ohio EPA 2005). Namely, State of Ohio EPA (2005) pointed out that if HELP runs for 5 years or less, it is likely that flow equilibrium has not been reached during the simulation and suggests to assume the change in water storage as an indicator of whether moisture and flow equilibrium has been achieve during the simulation.

To assess the relevance of the different processes leading to leachate production, the contribution of each term of the water balance described in this work was calculated (Fig. 4). The obtained results suggest that, in this specific case, the key processes leading to leachate generation are water release (about 24-26\%) and rainfall (24-26\%), whereas evapotranspiration and runoff contribute to the budget to a lesser extent ( 2 and $9 \%$, respectively). It is worth noting that runoff occurs only during 2012, when the effective height of disposed wastes (computed taking into account for settlements) exceeds the trench one. Water consumption due to biodegradation process occurs at the second year of simulation, as expected by applying triangular pattern (Tchobanoglous et al. 1993) and, in this case, 
Fig. 4 Percentage contributions of each parameters of the water balance described in Eq. 1, relating to the 4 years of landfill simulation. The percentage of each parameter $p_{i}$ is computed as: $\%\left(p_{i}\right)=\frac{\left|p_{i}\right|}{\left(\left|p_{i}\right|+\left|p_{j}\right|+\cdots\left|p_{n}\right|\right)}$
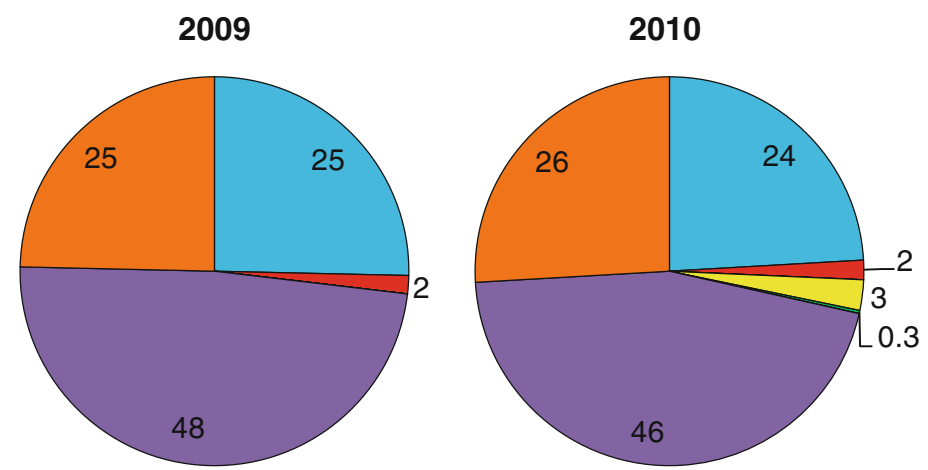

$\square$ Rainfall

Evapotranspiration

Runoff

Biotic consumption
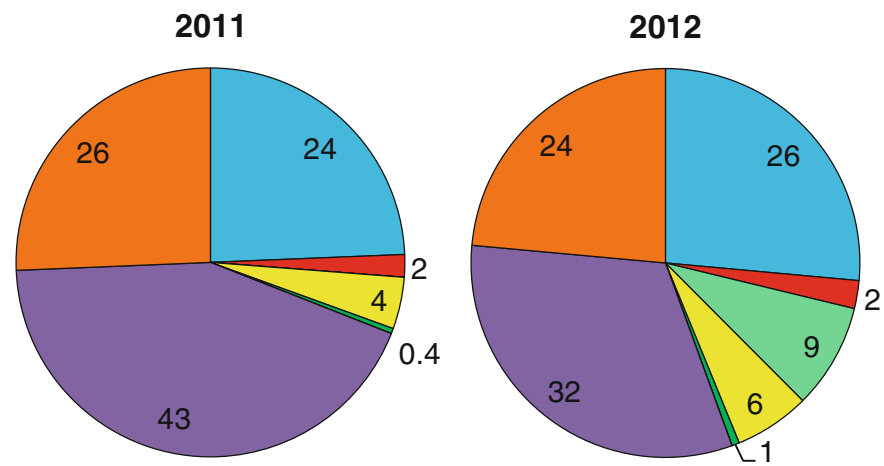

Vapor

$\square$ Retention

Leachate

Release is in the order of 3-6\%. Finally, vapor losses during gas extraction are very small $(<1 \%)$ and, according to São Mateus et al. (2012), can be neglected.

\section{Limitations of the developed model}

In view of the results shown above, it can be stated that the proposed water balance model can be used as screening tool to evaluate leachate production in landfills. However, it should be pointed out that the developed model uses analytical and empirical equations which are based on different simplifying assumptions. For instance, it assumes that composition and properties of landfilled wastes (moisture, density, porosity and field capacity) do not change throughout the year despite characteristics of solid waste are expected to vary seasonally. Moreover, water balance for each layer is performed assuming a completely mixed layer; this inability to describe the heterogeneity of the medium may lead to some shortcomings, especially when trying to apply the model to a very short time interval. Finally, further applications should be performed in order to assess the model's performances and to detect other possible limitations.

\section{Conclusion}

In this paper, a water balance model for predicting leachate in landfills was presented. The developed model allows to simulate the filling operations of an active landfill by discretizing the whole system in different hydraulically interconnected and customizable cells. In addition, the aftercare periods can also be simulated by introducing information about the capping system. For each layer, the proposed model applies a water balance accounting for all the main parameters and processes affecting leachate production (e.g., biodegradation, gas production and biotic consumption, waste aging and compression), as well as their temporal variation by applying simple empirical and analytical equations. In order to assess the influence of these parameters and processes on leachate estimation, several simulations assuming different hypothetical scenarios have been carried out. The obtained results were compared with those of HELP, which neglects both biodegradation and waste compression processes. The results showed that wastes compression phenomena affect leachate prediction in a large extent during operative stage of landfill and neglecting these processes could lead to underestimation up to one order of magnitude. Also biodegradation of wastes organic matter may results relevant for leachate volumes assessment, influencing water storage capacity of wastes and leading to a leachate production 2-3 times greater than those obtained neglecting these phenomena. Finally, an application of the developed model to a real landfill was presented. The obtained results showed a quite good agreement with the landfill measurements of the leachate flow in the final collection pipe, which are 
encouraging for continuing the development and refinement of the model.

Acknowledgments The Authors wish to thank Prof. Piero Sirini of the University of Florence for his inspirational ideas in the initial development of the model and Fabio Ermolli of ARPA Lazio and Marco Sanna for providing useful information and data.

\section{List of symbols}
$A\left[L^{2}\right]$
$A_{g}\left[L^{2}\right]$
$B[L]$
$\mathrm{CC}_{\mathrm{c}}\left[M / L^{2}\right]$
$\mathrm{CS}_{\max }\left[L^{3}\right]$
$\mathrm{D}_{\mathrm{c}}[L]$

$d_{f}[L]$
$\mathrm{ET}_{r}\left[L^{3}\right]$
$\mathrm{FC}_{\text {soil }}\left[L^{3} / L^{3}\right]$
$\mathrm{FC}_{w}\left[L^{3} / L^{3}\right]$
$\mathrm{FC}_{w, 0}\left[L^{3} / L^{3}\right]$
$\mathrm{FC}_{w, l i m}\left[L^{3} / L^{3}\right]$
$I_{\text {ef }}[L]$
$K_{c}[L / T]$
$K_{d}[L / T]$
$K_{g}[L / T]$

$L\left[L^{3}\right]$

$M_{w}[M]$

$M_{\text {deg }}[M]$

$M_{\mathrm{dry}, w}[M]$

$M_{\mathrm{H}_{2} \mathrm{O}}[M]$

$M_{k}[M]$

$M_{m, k}[M]$

$M_{\text {soil }}[M]$

$M_{\text {tot }}[M]$

$n\left[L^{3} / L^{3}\right]$

$p\left[M / L^{2}\right]$

$P\left[L^{3}\right]$

$P_{v, \text { sat }}\left[M / L^{2}\right]$

$\mathrm{PM}_{\mathrm{H}_{2} \mathrm{O}}[M / N]$

$\mathrm{PM}^{\mathrm{SBOF}}[M / N]$

$\mathrm{PM}^{\mathrm{RBOF}}[M / N]$

$Q_{\text {biogas }}\left[L^{3} / T\right]$

$Q_{\text {in }}\left[L^{3}\right]$

$Q_{\text {lat }}\left[L^{3}\right]$

$R\left[L^{3}\right]$

$R_{g}\left[\mathrm{ML}^{2} / T^{2} N \Theta\right]$

$s_{c}[L]$

$s_{\mathrm{g}}[L]$

$t_{\mathrm{deg}}[T]$

$t_{\text {peak }}[T]$
Exposed area

Geosynthetic area

Cell size

Compressibility coefficient

Waste retention capacity

Distance cell-collection

system

Defects diameter

Evapotranspiration

Cover soil field capacity

Waste field capacity

Initial waste field capacity

Waste wilting point

Effective infiltration

Clay hydraulic conductivity

Drain hydraulic conductivity

Geosynthetic hydraulic

conductivity

Leachate production

Initial waste mass

Degraded waste dry mass

Waste dry mass

Water mass in layer

Percentage weight of MSW fraction

Waste fraction dry mass

Cover soil mass

Total mass of upper layer

Waste porosity

Gas pressure

Rainfall

Water molecular mass

SBOF molecular mass

RBOF molecular mass

Biogas rate production

Water passing through

capping

Lateral drainage

Runoff

Universal gas constant

Clay thickness

Geosynthetic thickness

Decomposition time

Peak time of gas production
Saturated vapor pressure
$T[\Theta]$

$u_{r}\left[L^{3} / L^{3}\right]$

$V_{\text {biogas }}\left[L^{3}\right]$

$V_{\text {deg }}\left[L^{3}\right]$

$V_{m}\left[L^{3}\right]$

$V_{\text {soil }}\left[L^{3}\right]$

$V_{v}\left[L^{3}\right]$

$V_{w}\left[L^{3}\right]$

$w_{k}[M / M]$

$W_{\text {bio }}\left[L^{3}\right]$

$W_{\text {in }}\left[L^{3}\right]$

$W_{\text {rel }}\left[L^{3}\right]$

$W_{\text {res }}\left[L^{3}\right]$

$W_{\text {ret }}\left[L^{3}\right]$

$W_{\text {ret,soil }}\left[L^{3}\right]$

$W_{\text {vap }}\left[L^{3}\right]$

$W_{\mathrm{w}}\left[L^{3}\right]$

$\alpha\left[\mathrm{NH}_{2} \mathrm{O} / \mathrm{N}^{\mathrm{f}}\right]$

$\Delta H[L]$

$\Delta U\left[L^{3} / L^{3}\right]$

$\eta[-]$

$\theta_{\text {soil }}\left[L^{3} / L^{3}\right]$

$\rho_{\mathrm{H}_{2} \mathrm{O}}\left[M / L^{3}\right]$

$\rho_{k}\left[M / L^{3}\right]$

$\rho_{w}\left[M / L^{3}\right]$

$\sigma_{s}\left[M / L^{2}\right]$

Temperature

Relative humidity of gas

Biogas volume

Degraded waste volume

Dry waste material volume

Cover soil volume

Pores volume

Total waste volume

Moisture of MSW fraction

Biotic water consumption

Incoming water in layer

Water released by waste

Residual water in waste

Water retained by waste

Retained water by cover soil

Vapor losses

Waste water content

Biotic water consumption

Water head

Change in water content

Defects number

Cover soil moisture

Water density

Waste fraction density

Waste wet density

Overburden pressure

\section{References}

Aronica S, Bonanno A, Piazza V, Pignato L, Trapani S (2009) Estimation of biogas produced by the landfill of Palermo, applying a Gaussian model. Waste Manag 29(1):233-239

Behera SK, Park JM, Kim KH, Park HS (2010) Methane production from food waste leachate in laboratory-scale simulated landfill. Waste Manag 30(8-9):1502-1508

Berger K (2000) Validation of the hydrologic evaluation of landfill performance (HELP) model for simulating the water balance of cover systems. Environ Geol 39(11):1261-1274

Bicheldey TK, Latushkina EN (2010) Biogass emission prognosis at the landfills. Int J Environ Sci Tech 7(4):623-628

De Velásquez MTO, Cruz-Rivera R, Rojas-Valencia N, MonjeRamírez I, Sánchez-Gómez J (2003a) Serial water balance method for predicting leachate generation in landfills. Waste Manag Res 21(2):127-136

De Velásquez MTO, Cruz-Rivera R, Rojas-Valencia N, MonjeRamírez I, Sánchez-Gómez J (2003b) Determination of field capacity of municipal solid waste with surcharge simulation. Waste Manag Res 21(2):137-144

Di Bella G, Di Trapani D, Mannina G, Viviani G (2012) Modeling of perched leachate zone formation in municipal solid waste landfills. Waste Manag 32(3):456-462

Fellner J, Brunner PH (2010) Modeling of leachate generation from MSW landfills by a 2-dimensional 2-domain approach. Waste Manag 30(11):2084-2095

Fellner J, Döberl G, Allgaier G, Brunner PH (2009) Comparing field investigations with laboratory models to predict landfill leachate emissions. Waste Manag 29(6):1844-1851 
Gawande NA, Reinhart DR, Yeh GT (2010) Modeling microbiological and chemical processes in municipal solid waste bioreactor, part 1: development of a three-phase numerical model BIOKEMOD-3P. Waste Manag 30(2):202-210

Giroud JP, Bonaparte R (1989) Leakage through liners constructed with geomembranes - Part I. Geomembr Liners Geotext Geomembr 8(1):27-67

Han B, Scicchitano V, Imhoff PT (2011) Measuring fluid flow properties of waste and assessing alternative conceptual models of pore structure. Waste Manag 31(3):445-456

Kale SS, Kadam AK, Kumar S, Pawar NJ (2010) Evaluating pollution potential of leachate from landfill site, from the Pune metropolitan city and its impact on shallow basaltic aquifers. Environ Monit Assess 162(1-4):327-346

Kindlein J, Dinkler D, Ahrens H (2003) Verification and application of coupled models for transport and reaction processes in sanitary landfills. In Proceedings of the 9th International Waste Management and Landfill Symposium, Cagliari, Italy, 6-10 Oct

Laner D, Fellner J, Brunner PH (2011) Future landfill emissions and the effect of final cover installation-a case study. Waste Manag 31(7):1522-1531

Lobo AG, Tejero I (2007) MODUELO 2: a new version of an integrated simulation model for municipal solid waste landfills. Environ Model Softw 22(1):59-72

Lobo A, Herrero J, Montero O, Fantelli M, Tejero I (2002) Modeling for environmental assessment of municipal solid waste landfills (part 1: hydrology). Waste Manag Res 20:198-210

Lobo A, Muñoz Jofré J, Sanchez Román M, Tejero I (2003) Comparative analysis of three hydrological landfill models (MODUELO 1, HELP and MODUELO 2) through a practical application. In Proceedings Sardinia, 9th International Waste Management and Landfill Symposium, Cagliari, Italy, 6-10 Oct

Machado SL, Carvalho MF, Gourc JP, Vilar OM, do Nascimento JC (2009) Methane generation in tropical landfills: simplified methods and field results. Waste Manag 29(1):153-161

Machado SL, Karimpour-Fard M, Shariatmadari N, Carvalho MF, Nascimento JCD (2010) Evaluation of the geotechnical properties of MSW in two Brazilian landfills. Waste Manag 30(12): 2579-2591

Münnich K, Bauer J, Fricke K (2009) Laboratory tests to determine water balance parameters of MBT material. In: Third International Workshop Hydro-Physico-Mechanics of landfills". Braunschweig, Germany, 10-13 March

Murthy VK, Manandhar DR, Kasaju YS (2009) Estimation of landfill leachate from a lysimeter of a pilot scale and feasibility of treatment by constructed wetland technology. In: Proceedings Sardinia, 12th International Waste Management and Landfill Symposium, Cagliari, Italy 5-9 Oct

Olivier F, Gourc J (2007) Hydro-mechanical behavior of municipal solid waste subject to leachate recirculation in a large-scale compression reactor cell. Waste Manag 27(1):44-58

Oni OAG (2010) Numerical simulation of the mass flow of leachate in a municipal waste fill (part 1)-closed recycling flow systems. J Appl Sci Res 6(6):742-750

Oni OA, Okunade E (2009) A basic investigation into the hydrophysical properties of emplaced waste lifts in a MSW landfill. Aust J Basic Appl Sci 3(2):628-643

Papadopoulou MP, Karatzas GP, Bougioukou GG (2007) Numerical modelling of the environmental impact of landfill leachate leakage on groundwater quality-a field application. Environ Model Assess 12(1):43-54

Powrie W, Hudson AP, Beaven RP (2000) Development of sustainable landfill practices and engineering landfill technology. Final report to the Engineering and Physical Sciences Research Council GR/L 16149
Rawat M, Ramanathan AL (2011) Assessment of methane flux from municipal solid waste (MSW) landfill areas of Delhi. India J Environ Prot 2(4):399-407

Reddy KR, Hettiarachchi H, Gangathulasi J, Bogner JE (2011) Geotechnical properties of municipal solid waste at different phases of biodegradation. Waste Manag 31(11):2275-2286

Renou S, Givaudan JG, Poulain S, Dirassouyan F, Moulin P (2008) Landfill leachate treatment: review and opportunity. J Hazard Mater 150(3):468-493

São Mateus MDSC, Machado SL, Barbosa MC (2012) An attempt to perform water balance in a Brazilian municipal solid waste landfill. Waste Manag 32(3):471-481

Schnabel WE, Munk J, Lee WJ, Barnes DL (2012) Four-years performance evaluation of a pilot-scale evapotranspiration landfill cover in Southcentral Alaska. Cold Reg Sci Technol $82: 1-7$

Schroeder PR, Dozier TS, Zappi PA, McEnroe BM, Sjostrom JW, Peyton RL (1994) The hydrologic evaluation of landfill performance (HELP) model. Engineering documentation for version 3. EPA/600/R-94/168b, U.S. Environmental Protection Agency, Cincinnati, OH, USA

Shariatmadari N, Abdoli MA, Ghiasinejad H, Mansouri A, Alimohammadi P (2010) Analysis of Help Model Application in SemiArid Areas. Study Tehran Test Cells Int J Civ Eng 8(2):174-186

Sirini P, Tchobanoglous G, Noto La Diega RC (2010) Ingegneria dei rifiuti solidi. Mc Graw Hill, Milano

Sivakumar D (2012) Experimental and analytical model studies on leachate volume computation from solid waste. Int J Environ Sci Tech, 1-14

Sivakumar D (2013) Adsorption study on municipal solid waste using Moringa oleifera seed. Int J Environ Sci Tech 10:113-124

State of Ohio EPA (2005) Using the HELP Model to Design the Leachate Collection and Management System. Division of Solid and Infectious Waste Management, Guidance Document \#0528

Staub M, Galietti B, Oxarango L, Khire MV, Gourc JP (2009) Porosity and hydraulic conductivity of MSW using laboratoryscale tests. In: Third International Workshop Hydro-PhysicoMechanics of landfills". Braunschweig, Germany, 10-13 March

Stoltz G, Gourc JP, Oxarango L (2010) Characterisation of the physico-mechanical parameters of MSW. Waste Manag 30(8): 1439-1449

Tchobanoglous G, Theisen H, Vigil SA (1993) Integrated solid waste management, engineering principles and management issues. Mc Graw Hill, New York

Thomsen NI, Milosevic N, Bjerg PL (2012) Application of a contaminant mass balance method at an old landfill to assess the impact on water resources. Waste Manag 32(12):2406-2417

USDA, Soil Conservation Service (1985) National engineering handbook, section 4, hydrology. US Government Printing Office, Washington

Vavilin VA (2010) Anaerobic degradation of organic waste: an experience in mathematical modeling. Microbiol 79(3):334-341

Venkatraman K, Ashwath N, Su N (2011) Predicting the site water balance of a phytocapped landfill using HYDRUS 1D. Int $\mathrm{J}$ Environ Sci Tech 14(1):269-281

White JK, Beaven RP (2013) Developments to a landfill processes model following its application to two landfill modeling challenges. Waste Manage, in press

White J, Robinson J, Ren Q (2004) Modelling the biochemical degradation of solid waste in landfills. Waste Manag 24(3):227-240

Wu H, Wang H, Zhao Y, Chen T, Lu W (2012) Evolution of unsaturated hydraulic properties of municipal solid waste with landfill depth and age. Waste Manag 32(3):463-470 
Zacharof AI, Butler AP (2004) Stochastic modelling of landfill leachate and biogas production incorporating waste heterogeneity. Model formulation and uncertainty analysis. Waste Manag 24(5):453-462
Zaman AU (2010) Comparative study of municipal solid waste treatment technologies using life cycle assessment method. Int J Environ Sci Tech 7(2):225-234 